\title{
Implikasi Konvergensi Media Terhadap Industri "Premateur Industri Penyiaran Televisi Digital pada Teknologi Layanan Mobile Television di Indonesia"
}

Implications of the Industry by Media Convergence "Digital Television Broadcasting Industry Premateur on Mobile Television Service Technology in Indonesia"

\author{
Danang Trijayanto \\ Dosen Ilmu Komunikasi, Universitas 17 Agustus 1945 Jakarta \\ Jalan Sunter Permai Raya-Sunter Agung Podomoro Jakarta 14350
}

danang.trijayanto@uta45jakarta.ac.id

\begin{abstract}
Media convergence was born and extended on the aspects of the people life. New media has been penetrate the growing industry related to media convergence. There are convergence of technology and industry convergence. Mobile Television (Mobile $T V)$ is television services by mobile devices. This paper describes the dynamic of mobile TV in the world, especially in Indonesia. Industry of television broadcasting and telecommunication industry are integrated in industry convergence on mobile TV service. Finally, broadcast industry depends on public acceptance.
\end{abstract}

Keyword: Media convergence, Mobile TV, Broadcasting, Industry, Telecommunication 


\begin{abstract}
Abstraksi:
Media lahir dan berpengaruh pada aspek kehidupan masyarakat. Media baru telah menembus industri, berkembang dengan konvergensi media. Ada konvergensi teknologi dan konvergensi industri. Ponsel Televisi (Mobile TV) adalah layanan televise dengan perangkat mobile. Makalah ini menjelaskan dinamisisasi mobile TV di dunia, khususnya di Indonesia. Industri penyiaran televisi dan industry telekomunikasi yang terintegrasi dalam sebuah konvergensi industri pada layanan mobile TV. Akhirnya, industri mobile TV tergantung pada penerimaan publik.
\end{abstract}

Kata kunci: Mobile TV, Penyiaran, Industri,Telekomunikasi, konvergensi Media. 


\section{PENDAHULUAN}

Saat ini dunia komunikasi mengalami proses perubahan memasuki era new media. Perkembangan new media atau internet, turut mengembangkan berbagai produk dan perubahan dalam kehidupan masyarakat. Perubahan tersebut melingkupi berbagai sektor atau bidang seperti sosial, politik, ekonomi, teknologi, dll. Keterpaduan teknologi dengan jaringan internet atau yang saat ini dikenal dengan istilah konvergensi media memberikan pengaruh yang bermacam-macam dalam kehidupan masyarakat.

Dalam era konvergensi media, segala macam yang berhubungan dengan internet memunculkan dunia baru juga. Secara konvensional, dahulu kita mengenal suatu media hanya berguna sesuai fungsi dari barang tersebut, namun sekarang dalam satu perangkat media dapat mengakses berbagai fungsi media lainnya. Sesuatu yang menarik dan menjadi jutaan perhatian sebagian besar masyarakat dari berbagai macam media, salah satunya adalah televisi. Media untuk menonton televisi, sebelum menggunakan perangkat konvergensi (ponsel, komputer, dll) mendorong kita untuk memiliki satu perangkat yang dalam operasional hanya untuk menonton, yaitu televisi.

Dengan pengaruh kehadiran komputer dan telepon seluler, menonton televisi dapat juga dilakukan dengan perangkat lainnya yang kita kenal dengan komputer atau telepon seluler. Di dalam perangkat tersebut, kita hanya perlu untuk menginstal 
software yang berisi aplikasi yang ingin kita gunakan. Semakin mudah ketika program televisi tersebut dapat disimpan dalam memori komputer atau telepon seluler. Hadirnya komputer dan teknologi telepon seluler mendorong perkembangan di berbagai industri, seperti industri penyiaran televisi, radio dan content (industri kreatif) untuk menghadirkan produk-produk atau program siaran secara digital.

Fenomena kehadiran teknologi mobile $T V$ mendunia dan menyentuh berbagai industri, baik dalam industri penyiaran maupun industri telekomunikasi, serta memiliki dampak yang berhubungan dengan penggunanya. Paper ini menggambarkan tentang dinamika teknologi layanan mobile $T V$ tersebut dalam penyelenggaraannya yang mendunia, dan ketika masuk di Indonesia.

Sehingga ada beberapa pokok bahasan yang akan didiskusikan dengan adanya konvergensi media tersebut (mobile TV) implikasinya terhadap industri, khususnya industri dari sudut pandang teknis atau teknologi dan sudut pandang industri komunikasi atau industri media yaitu stasiun televisi.

\section{PEMBAHASAN}

\section{A. Konvergensi Media}

Proses komunikasi melibatkan media serta teknologi internet atau akses data. Perkembangan konvergensi media tersebut berimplikasi pada ranah industri. Korporasi yang 
banyak berinvestasi pada industri ini, misalnya adalah perusahan yang bergerak dalam bidang telekomunikasi dan penyiaran. Infrastruktur pendukung layanan, penyediaan layanan (content) dan perangkat (handheld) bagi user merupakan peluang bagi korporasi atau perusahaan dalam mengembangkan produknya. Infrastruktur adalah faktor utama dalam tersedianya jaringan, yang akan menjadikan ada atau tidak, lancar dan tidaknya akses dalam berkomunikasi. Perkembangan pemanfataan infrastruktur menjadi lahan investasi yang luas bagi industri telekomunikasi untuk menyediakan berbagai layanan atau content untuk pengguna jasa layanan telekomunikasi, bahkan industri perangkat gadget (telepon seluler, tablet $p c$, televisi) semakin berinovasi menciptakan produk-produk baru yang mendukung teknologi konvergensi tersebut.

Konvergensi media melibatkan beberapa sektor, yaitu jaringan komunikasi, komputerisasi atau teknologi informasi dan beragam isi yang disediakan oleh media. Dari gambar berikut, Flew (2005) menjelaskan bahwa ketiga elemen tersebut akan saling berhubungan dengan yang namanya mobile telephony, cable tv interactive dan content provider, hubungannya dapat dilihat dalam gambar berikut: 


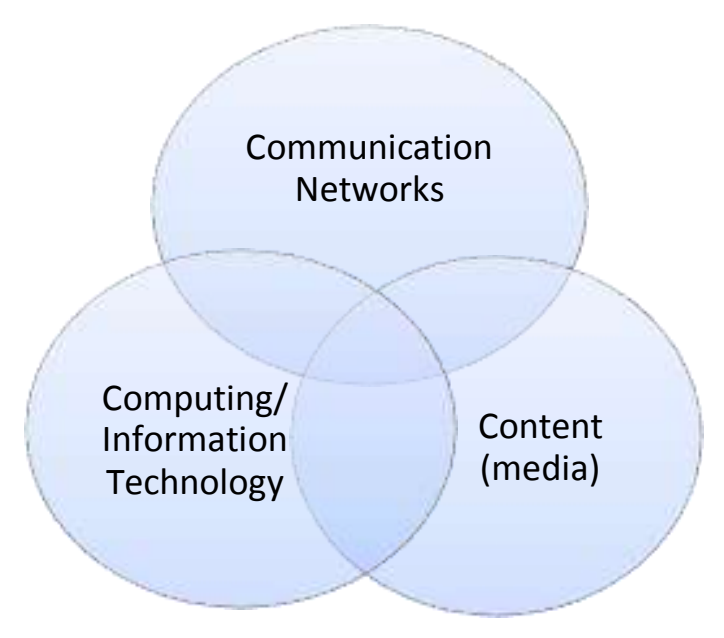

Gambar: Tiga relasi dalam konvergensi media

Dijelaskan juga oleh Flew (2005) bahwa media internet merupakan bentuk media baru. Program televisi, majalah, buku, surat kabar dan bentuk media cetak lainnya tidak termasuk dalam media baru, kecuali program tersebut tersaji dengan jaringan internet. Lister, dkk (2003) juga menjelaskan bahwa internet, video games dan telepon seluler merupakan bentuk media baru dalam kehidupan masa kini.

Konvergensi media terjadi ketika unsur-unsur tersebut terhubung dengan jaringan internet dan dapat terakses pada suatu perangkat terpadu, sehingga fungsional dari masingmasing media dapat diadopsi oleh suatu bentuk media.

Setelah terhubungnya jaringan internet ke dalam suatu platform media, maka sudah pasti yang terjadi adalah konvergensi media. Konvergensi merambah juga pada teknologi yang membentuk konvergensi industri. Konvergensi 
industri telah melibatkan serangkaian pengambilalihan, merger,dan aliansi strategis yang memperkuat hubungan antara komputasi dan industri IT, perusahaan telekomunikasi, dan sektor media (Flew 2005).

Hubungan antara konvergensi media terhadap industri dan layanan mobile $T V$ dapat digambarkan sebagai berikut:

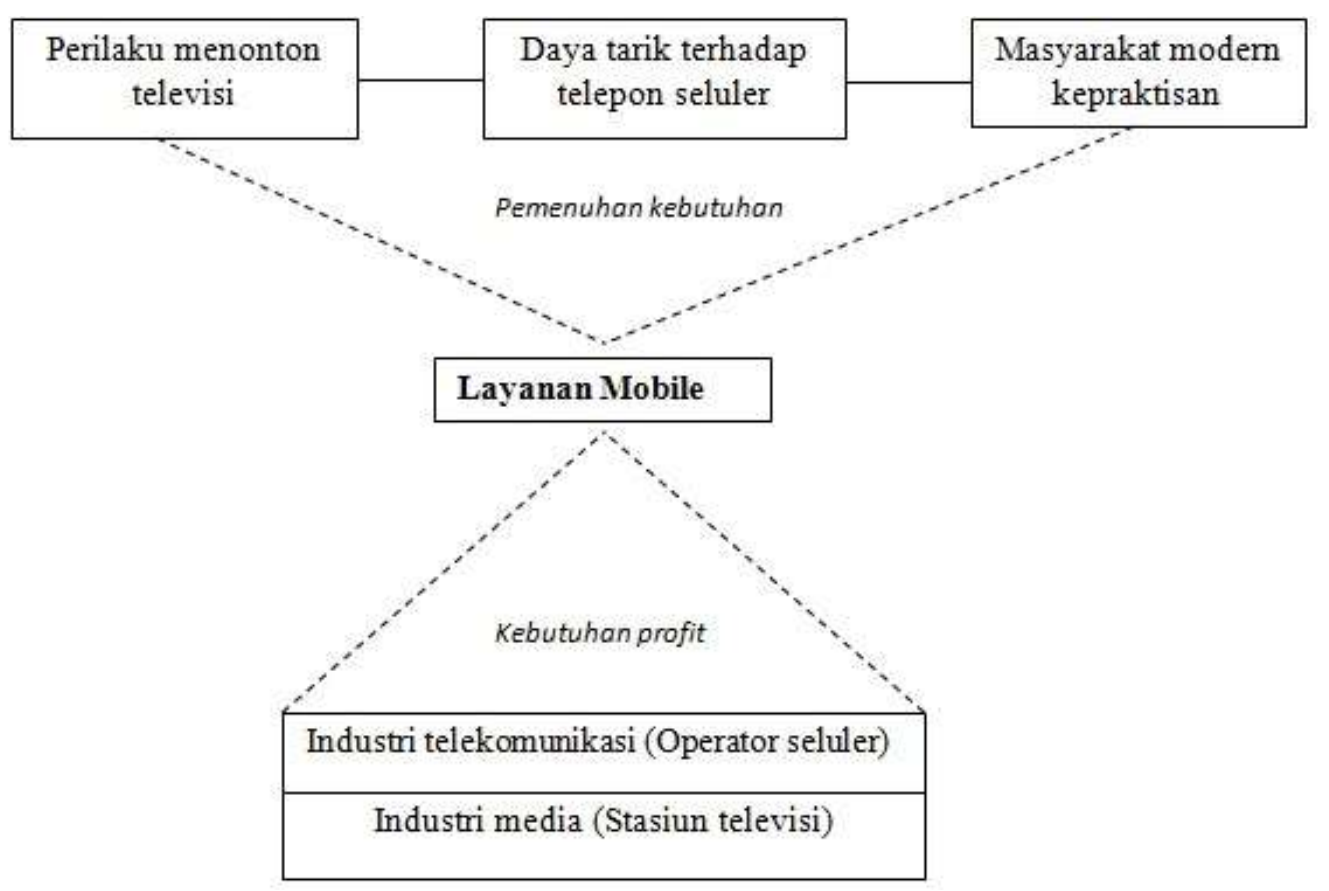

Lavanan Mobile TV 
Maka dari teori-teori yang telah dijelaskan di atas, program televisi atau video yang diakses melalui teknologi mobile atau telepon seluler (Layanan Mobile TV) dikategorikan sebagai suatu bentuk konvergensi media. Sebagai sebuah perangkat, mobile telephone adalah perangkat new media, pengoperasiannya membutuhkan teknologi telekomunikasi dengan layanan siaran televisi dari industri media atau stasiun televisi.

\section{B. Industri Layanan Mobile TV di dunia dan Implementasinya di Indonesia}

1) Penyiaran Mobile TV Digital

Pertemuan antara lahirnya teknologi dan berkembangnya permintaan konsumen atas pilihan dan kontrol mengubah definisi mendasar mengenai televisi dan model bisnis penyiaran. Penyiaran modern harus mempertimbangkan pemasaran dan penyiaran televisi sebagai bisnis dalam berbagai platform siaran, yaitu: layar siaran televisi di rumah, saat online dan secara mobile. Industri penyiaran harus mampu menghasilkan benefit dari isi siaran di platform media milik khalayak tersebut. Sebelum membahas tentang alasan indutri-industri yang merambah konvergensi media akibat era new media terlebih dahulu harus dilihat apa saja yang mendorong industri tersebut dalam mengembangkan layanan-layanan 
produk konvergensi media. Faktor masyarakat atau khalayak tentunya menjadi faktor yang menjadi pertimbangan bagi industri penyiaran mengikuti layanan mobile $T V$ ini. Pertimbangan respon khalayak terhadap layanan mobile TV melalui riset yang pernah dilakukan.

Saat ini sebagian besar negara di seluruh penjuru dunia telah menerapkan sistem penyiaran secara digital yang dikenal dengan TV digital (DTV). Banyak keuntungan yang diperoleh dengan sistem penyiaran ini, seperti: kualitas gambar dan suara yang lebih baik, jumlah peningkatan jumlah saluran penyiaran, dan layanan multimedia interaktif. Dalam sistem siaran DTV, dua standar yang dominan diterapkan adalah adalah $D V B-T$ (Digital Video Broadcasting-Terrestrial) di eropa dan ISDB-T (Intrgrated Jasa Penyiaran Digital-Terrestrial) di Jepang dan Brasil. Standar TV digital juga akan memfasilitasi pelaksanaan resepsi video atau penyelenggaran siaran televisi pada telepon seluler dan multimedia perangkat seluler. Standar untuk televisi pada telepon seluler atau mobile $T V$ tersebut menggunakan standard siaran eropa yang dikembangkan dalam bentuk DVB-H (DVB-Handheld). Sistem siaran digital TV untuk perangkat mobile lainnya yang berkembang di seluruh dunia dengan teknologi terestrial atau satelit, diantaranya adalah Media FLO (Forward Link Only) dan ATSC-mobile 
di Amerika Serikat, DMB-T (Digital Multimedia Broadcasting) dan $C M M B$ satelit berbasis di China dan $T$ $D M B$ di korea (Youssef dan Haslett 2010).

Secara komersil ada beberapa negara yang sudah mengimplementasikan mobile $T V$ dengan standarisasi penyiaran yang berbeda-beda. Negara-negara tersebut adalah:

\begin{tabular}{|l|c|c|c|}
\hline Negara & Standard & Start & $\begin{array}{c}\text { Jumlah } \\
\text { Pengguna }\end{array}$ \\
\hline Jepang & ISDB-T & - & $>25.000 .000$ \\
\hline Korea & T-DMB & $12 / 2005$ & $>15.000 .000$ \\
\hline Korea & S-DMB & $05 / 2006$ & $>2.000 .000$ \\
\hline Italia & DVB-H & $05 / 2006$ & 850.000 \\
\hline Belanda & DVB-H & $06 / 2008$ & 10.000 \\
\hline
\end{tabular}

Sumber: Hamdani (2011)

Hamdani (dalam Broadcastmagz 2011) menjelaskan bahwa dahsyatnya penggunaan ponsel pada akhirnya membuktikan bahwa layanan telekomunikasi juga menuntut layanan yang personal dan bisa bergerak sesuai pemiliknya. Hal ini juga pada akhirnya diprediksi akan menjadi tuntutan pada layanan TV digital berbasis mobile dan layanan video, sehingga penyelenggara layanan juga harus bisa memberikan layanan yang personal dan bisa bergerak sesuai pemiliknya. Hal ini diprediksi dengan kemunculan mobile $T V$ yang bisa 
melebihi IPTV (Internet Protocol Television) di tahun 2010. Pada tahun 2010, mobile TV akan mencapai 250 juta pelanggan sedangkan IPTV diprediksi akan mencapai 50 juta pelanggan, adapun internet TV yang dapat dinikmati melalui $D S L$ dapat mencapai 300 juta pelanggan. Dengan prediksi tersebut maka mobile $T V$ merupakan suatu keniscayaan yang pasti terjadi di dunia, maka tidak mengherankan sampai saat ini di dunia sudah mencapai 170 perusahaan yang meluncurkan mobile $T V$ di mana lebih dari 150 perusahaan mobile telecommunication yang terlibat di dalamnya, dan perusahaan seperti Ericsson sebagai pemain utamanya.

Sebuah studi dari ABI Research, seperti dijelaskan oleh Kitson (2010) memprediksi bahwa akan ada 500 juta pemirsa TV mobile pada tahun 2013, dan pasar TV mobile akan bernilai lebih dari \$ 50 miliar. Sebuah pembangkit bagi pertumbuhan ini adalah konversi di AS dan wilayah lainnya untuk semua transmisi TV digital, yang akan mendorong peluang bagi over-the-air TV broascasts langsung ke perangkat mobile menggabungkan $T V$ tuner. Pada pameran tahun 2009, The International Consumer Electronic Show in Las Vegas, The Open Mobile Video Coalition (OMVC) mengumumkan bahwa 63 stasiun di 22 kota di Amerika Serikat berkomitmen untuk menyediakan 
over-the-air televisi digital untuk perangkat mobile di tahun 2009.

Rujukan lain dijelaskan Dharmanto (dalam Broadcastmagz 2011) yang didapat dari Informa Telecoms \& Media, yang memprediksi bahwa layanan mobile multimedia mobile $T V$ akan terus mengalami perkembangan yang pesat sejalan dengan pertumbuhan pengguna mobile phone yang diperkirakan meningkat dari jumlah 2,6 milyar di tahun 2006, menjadi 4,9 milyar pengguna di tahun 2012. Hal ini tentu akan menjadi pasar yang sangat potensial bagi penyedia layanan mobile $T V$, yaitu bagi industri di bidang telekomunikasi dan industri penyiaran televisi.

Fenomena di negara Asia, dijelaskan Spry selaku Chief Eksekutif Nielson Research (dalam AGB Nielsen 2009), sehubungan dengan perkembangan siaran digital, Pertumbuhan GDP (Gross Domestic Product) yang kuat telah menggiring pada pendapatan bersih yang lebih tinggi di semua negara Asia dalam lima tahun terakhir, dan kemakmuran ini telah membantu industri TV berbayar dan pita lebar tumbuh lebih dari $20 \%$ per tahun, namun Asia memiliki pasar yang berbeda-beda dan pengaplikasian media digital di berbagai wilayah. Langkah nyata telah diambil di Jepang, Korea, Hong Kong, Singapura dan Malaysia, negara lainnya terutama di Asia Tenggara, 
seperti: Thailand, Indonesia, Filipina dan Vietnam belum menunjukkan kecepatan perkembangan media digital yang sama, masih tertinggal jauh dari para tetangganya dalam hal penggunaan internet dan penetrasi TV berbayar, khususnya Internet Protocol Television (IPTV). Permasalahannya lebih daripada sekedar kekurangan cakupan. Kapasitas dan kecepatan akses masih tidak dapat mendukung $I P T V$, selain pertumbuhan dalam penetrasi pita lebar. Mobile TV memiliki potensi yang sangat besar di Asia. Internet diakses lebih banyak melalui ponsel daripada komputer di Asia dan wilayah ini sudah mewakili 75\% dari kepemirsaan mobile $T V$ di dunia. Namun, perlu diingat bahwa kebanyakan kepemirsaan berada di Jepang dan Korea, dengan penggunaan mobile $T V$ yang masih kecil dalam proporsi penggunaan ponsel

Dalam kaitannya dengan penggunaan telepon seluler, Harkin (dikutip oleh Flew 2005) mengamati bahwa, meskipun kepemilikan dan penggunaan telepon seluler dimana-mana, para peneliti sebenarnya sedikit yang memiliki perhatian bagaimana ponsel tersebut digunakan, dan bagaimana penggunaan dari ponsel tersebut memiliki makna sosial bagi penggunanya. Keseringannya adalah mengemukakan bahwa ponsel menghasilkan perilaku anti sosial atau sebagian menganggapnya lebih dari sekedar mainan. Sebaliknya, penelitian Harkin menemukan bahwa 
dari sisi pengguna, daya tarik sebuah ponsel lebih menyangkut pada kepraktisannya, terkait dengan cara menemukan atau menyeleksi jaringan pertemanan, dan sejauh mana telepon seluler secara pribadi menyatakan pemiliknya (terutama di kalangan remaja). Budaya telepon seluler ini menjadi tantangan yang lebih fungsional. Memikirkan ponsel dalam contohnya, parameter pengguna banyak yang menggunakannya sebagai komputasi personal.

Berdasarkan riset tersebut, kita dapat melihat bahwa beberapa motif pengguna ponsel pada dasarnya karena kebutuhan dalam gaya hidup dan juga kebutuhan dalam kepraktisan perangkat yang mampu mengorganisir kebutuhan-kebutuhan pemiliknya. Maka dari sebuah ponsel, kebutuhan penggunapun akan dapat dilayani oleh penyedia layanan dalam berkomunikasi melalui perangkat tersebut. Dalam hal ini, kebutuhan akan hiburan atau entertainment, berita maupun informasi lainnya dapat diperoleh oleh pengguna melalui layanan mobile $T V$. Kebutuhan-kebutuhan tersebut dengan sengaja akan terus semakin dikembangkan untuk membentuk lahan industri bagi korporasi, dalam hal ini bagi produsen ponsel, penyelenggara siaran televisi maupun produsen jasa telekomunikasi. 
Sejalan dengan apa yang dijelaskan oleh Harkin, kemajuan teknologi telepon seluler yang mengadopsi kebutuhan setiap orang juga menuntut untuk selalu update menyediakan fitur dan layanan setiap orang, dalam hal ini kebutuhan terhadap ketergantungan media, seperti televisi.

Melihat respon khalayak terhadap akses televisi melalui ponsel dapat dilihat dari riset-riset yang pernah dilakukah oleh para pelaku riset. Penjelasan berikut ini adalah hasil riset atau studi yang dilakukan oleh Fleury, Pederson \& Larsen (2009) yang bertujuan untuk melihat dua aspek yang berbeda pada pengalaman penggunaan mobile television. Percobaan atau riset dalam aspek pertama adalah untuk menilai penerimaan penggunaan layanan mobile TV dalam konteks publik, sedangkan pada aspek kedua untuk menyelidiki perilaku pengguna sebagai bentuk motif yang mendorong kontribusi pengguna. Riset tersebut menunjukkan bahwa pengguna merasa nyaman dalam mengakses mobile TV (menonton televisi) dalam lingkungan sosial, namun harus dikombinasikan dengan penutup telinga (headset), dan studi kedua menemukan bahwa kepercayaan pada informasi dari penyelenggara layanan mobile merupakan faktor yang sangat penting bagi pengguna untuk dapat berkolaborasi dan berkontribusi dengan layanan konten. Siaran televisi yang diakses 
melalui ponsel tersebut adalah dengan teknologi frekuensi TV digital untuk telepon seluler.

Sedangkan riset yang dilakukan di Indonesia, adalah riset terhadap penerimaan atas layanan mobile $T V$ berbasis $3 G$ tentang penerimaan mobile $T V$ berbasis $3 G$ di Indonesia. Riset ini ditulis oleh Qiantori dkk (2010). Layanan $3 G$ mobile $T V$ ternyata masih minim peminatnya, terlihat dari kecilnya ARPU (Average Revenue Per User yaitu rata-rata pendapatan) yang diterima oleh penyelenggara layanan. Pengguna sendiri belum memiliki keputusan yang bernilai dalam mengadopsi layanan ini. Hal ini yang melatarbelakangi Qiantori dkk mengidentifikasi faktor yang mempengaruhi penerimaan pengguna terhadap layanan dengan menggunakan model penerimaan TAM (Technology Acceptance Model) dari Davis. Hasilnya adalah faktor penerimaan terhadap manfaat kegunaan, kenikmatan layanan, ketersediaan layanan, dan kualitas layanan ternyata berpengaruh positif terhadap sikap menggunakan layanan, dalam tingkat intensitas yang berbeda. Pengaruh terbesar berasal dari perceived of enjoyment (penikmatan), kemudian disusul oleh perceived of quality (kualitas layanan), avaibility (ketersediaan layanan kapanpun), dan usefulness (kegunaan layanan). Pengaruh terbesar adalah enjoyment. Pengaruhnya justru lebih besar dari manfaat kegunaan. 
Hasil tersebut memberikan fakta bahwa banyak pengguna lebih fokus pada nilai hiburan pada layanan tersebut daripada kegunaan layanan.

2) Implementasi Mobile TV di Indonesia

Televisi secara mobile atau bergerak atau lazim dikenal dengan ponsel $T V$ yang beroperasi di Indonesia saat ini dikenal dalam beberapa bentuk. Pertama, televisi yang beroperasi dengan ponsel berbasis $3 G$ atau layanan data operator telekomunikasi. Dengan tersedianya jaringan telekomunikasi berbasis $3 G$, saat ini sebagian stasiun televisi swasta nasional bekerja sama dengan pihak operator seluler untuk menjual program baik secara langsung, maupun dengan penjualan konten dengan cara mendownload siaran. Kedua, pengaksesan mobile TV atau televisi bergerak berbasis sistem broadcasting atau penyiaran digital bergerak (dengan sistem penyiaran $D V B$ $H$ ), untuk mengakses layanan mobile $T V$ ini, diperlukan perangkat ponsel dengan kemampuan menangkap siaran $D V B-H$ yang hanya dimiliki oleh ponsel-ponsel dengan brand tertentu, selain itu dapat diakses juga melalui jaringan $3 G$ karena ponsel-ponsel dengan sistem $D V B-H$ ini telah dilengkapi frekuensi layanan $3 G$ juga. Stasiun televisi yang menyelenggarakan layanan $D V B-H$ ini adalah MNC Group, TVRI dan stasiun televisi global lain seperti National Geograpich, CNN, dll dengan area jangkauan 
siaran yang hanya masih terbatas di wilayah Jakarta. Akses penyiaran televisi dengan sistem pertama dan kedua tersebut dikenakan biaya berlangganan kepada pihak operator. Ketiga, adalah mobile TV analog atau ponsel dengan daya tangkap jaringan televisi pada sistem analog atau tuner. Ponsel dengan kemampuan ini layaknya seperti perangkat $T V$ analog yang menangkap siaran dengan tuner dan pencarian siaran dengan menggunakan antena. Aktivitas menontonpun tanpa biaya atau gratis. Saat ini ponsel ini banyak beredar dipasaran hasil produksi dari negeri tirai bambu atau negara China. Penjualannyapun dibanderol dengan harga yang cukup murah.

Ada beberapa stasiun penyiaran televisi yang telah bekerja sama dengan pihak penyelenggara layanan telekomunikasi atau operator seluler untuk pelayanan mobile $T V$ melalui ponsel berbasis $3 G$. Bentuk layanan dan merger antar industri ini antara lain ada $i T V$ milik operator seluler Indosat. iTV memiliki layanan dengan channel televisi SCTV, Trans TV, Indosiar, Jak TV dan O Channel. Berikutnya, operator seluler Telkomsel melalui layanan Dunia $3 G$ nya dapat menyajikan layanan siaran televisi dari channel SCTV, Metro TV, O Channel, Indosiar, SpaceToon, Bali TV, Makasar TV, CNBC dan portal video. Operator lainnya adalah XL Axiata yang memiliki paket berlangganan $T V$ internasional secara bulanan (Aljazeera, 
Trace TV, BBC, dan Soundtrack Channel), dan paket berlangganan $S C T V$ serta $O$ Channel.

Mengikuti berbagai negara di berbagai belahan dunia yang telah menyelenggara infrastruktur penyelenggaraan mobile $T V$, Indonesia juga telah menggelar jaringan uji coba siaran mobile $T V$ yang dilaksanakan pada akhir tahun 2008. Uji coba tersebut, melalui Peraturan Menteri Melalui peraturan Menkominfo No.27/P/M.KOMINFO/8/2008, pemerintah telah memutuskan penyelenggaraan uji coba siaran $T V$ digital untuk perangkat bergerak (mobile TV) dilakukan oleh masing-masing penyelenggara yang berbentuk konsorsium. Keputusan tersebut adalah bahwa konsorsium PT Tren Mobile dan konsorsium lainnya, yaitu PT.Telkom, PT.Telkomsel dan PT. Indonusa Telemedia (Telkomvision) dapat menyelenggarakan uji coba penyelenggaran siaran mobile $T V$ berbasis standar $D V B-H$. Uji coba ini menggunakan kanal 24 dan 26 UHF, dengan durasi siaran sekurang-kurangnya 12 jam sehari dalam kurun waktu sembilan bulan.

Selama sembilan bulan tersebut untuk melakukan pengamatan terhadap kualitas dari layanan mobile $T V$ serta pengamatan terhadap, dan minat masyarakat terhadap siaran TV digital mobile tersebut. Keberhasilan ujicoba tersebut dijadikan refernsi dalam penyusunan regulasi 
implementasi sistem penyiaran digital dan sebagai bahan pertimbangan dalam seleksi penyelenggara penyiaran (korporasi) TV digital oleh pemerintah. Tepat pada tanggal 3 Agustus 2009, pemerintah lewat Depkominfo meresmikan uji coba lapangan siaran digital untuk penerimaan televisi bergerak (mobile TV) yang dilakukan oleh konsorsium (Tren Mobile) dan konsorsium (Telkom, Telkomsel dan Indonusa), sebagai berikut:

Tabel: Penyelenggara Layanan Mobile TV berbasis $D V B-H$ di Indonesia

\begin{tabular}{|c|c|c|}
\hline $\begin{array}{c}\text { Penyelenggaraan } \\
\text { Mobile TV }\end{array}$ & Konsorsium (Tren Mobile) & $\begin{array}{c}\text { Konsorsium (Telkom, Telkomsel dan } \\
\text { Indonusa) }\end{array}$ \\
\hline $\begin{array}{l}\text { Waktu } \\
\text { mengudara }\end{array}$ & Sejak 20 Februari 2009 & Sejak 20 April 2009 \\
\hline Kanal yang terisi & $\begin{array}{l}\text { 11 kanal sudah diisi seperti: RCTI (kanal } \\
\text { 1), TPI (MNCTV red-kanal 2),(Global } \\
\text { TV (kanal 3), MNC News (kanal } \\
\text { 4), MNC Music (kanal 5),MNC } \\
\text { Entertainment (Kanal 6),Cartoon Networ } \\
\text { k (kanal 7), CNN (kanal 8), Aljazeera } \\
\text { (kanal 9), Bloomberg } \\
\text { (kanal 10), dan TVRI (kanal 11) }\end{array}$ & $\begin{array}{l}8 \text { program dimana } 5 \text { program berupa } \\
\text { siaran yang kelak ditangkap secara free } \\
\text { yang meliputi Tenssport, CNN, Tres TV, } \\
\text { Spacetoon, dan TVRI, sedangkan } 3 \\
\text { program } \\
\text { diacak(scrambled)yang meliputi National } \\
\text { Geographic, National Adventure, dan } \\
\text { MGM } \\
\text { Sport. }\end{array}$ \\
\hline Frekuensi & $\begin{array}{l}24 \text { UHF dengan kekuatan } \\
500 \text { Watt yang akan ditingkatkan } \\
\text { menajdi 1,2 KWatt sehingga Tren Mobile }\end{array}$ & $\begin{array}{l}\text { Kanal } 26 \text { UHF dengan } \\
\text { menggunakan Single Frequensy Network } \\
(\text { SFN) karena menggunakan dua pemancar }\end{array}$ \\
\hline
\end{tabular}




\begin{tabular}{|l|l|l|}
\hline \multirow{2}{*}{$\begin{array}{l}\text { Perangkat yang } \\
\text { digunakan }\end{array}$} & $\begin{array}{l}\text { Ponsel atau telpon genggam } \\
\text { yang memiliki penerima DVBH. } \\
\text { Beberapa ponsel saat itu yang bisa } \\
\text { digunakan antara lain Nokia N96, N77, } \\
\text { dan N73 dengan tambahan eksternal } \\
\text { tuner SU33W, atau ZTE F912 dan PTMP } \\
\text { Motorola DH2 model touch screen }\end{array}$ & $\begin{array}{l}\text { Handset yang } \\
\text { bisa digunakan untuk menangkap siaran } \\
\text { dari konsorsium ini adalah Quantum PMP },\end{array}$ \\
\hline
\end{tabular}

Dari kerja sama yang terjadi bisa kita lihat bahwa respon industri penyiaran dan telekomunikasi terhadap konvergensi media memiliki antusias yang cukup tinggi. Seperti group MNC yang masuk dalam konsorsium Tren Mobile, yang mengambil sebagian besar kanal pada penyiaran televisi seluler berbasis digital broadcasting.

\section{III.KESIMPULAN}

Dengan majunya jaringan yang dapat diambil dan dikelola oleh suatu vendor telekomunikasi selular, maka semakin besar peluang bagi operator tersebut untuk menyajikan beragam layanan menarik yang dapat dijual kepada konsumen atau pelangganAntara penyelenggara industri layanan telekomunikasi dalam hal ini tentu memiliki hubungan kerjasama dengan industri penyelenggara siaran atau media. Kedua industri ini memiliki hitungan pembagian keuntungan 
dari penjualan program siaran Televisi mobile dengan dukungan dari pelanggan layanan selular. Kedua industri tersebut menjadikan mobile TV sebagai produk dalam era konvergensi media.

Dalam kelanjutannya, baik dari berbagai prediksi maupun riset yang dilakukan, potensial mobile $T V$ berbasis $3 G$ maupun $D V B-H$ tidak menjadi fenomenal dalam kebutuhan teknologi kehidupan masyarakat di Indonesia. Industri penyiaran khususnya, terkait dengan ujocoba yang telah dilakukan pada layanan mobile $T V$ berbasis $D V B-H$ di tahun 2009, hingga kini kelanjutan kiprahnya sudah tidak lagi terdengar. Padahal kualitas tontonan akan semakin lebih baik, selain bisa memperluas industri kreatif melalui layanan-layanan content yang sifatnya mendidik dengan pemanfaatan kanalkanal yang bisa diisi. Industri ini tidak begitu berkembang atau bisa dikatakan prematur. Dari dulu, penerapan teknologi di negara ini memang tidak ingin tertinggal dalam kemajuan, sehingga apapun selalu ingin diadopsi. Alih-alih dapat menerapkan, masih banyak adopsi teknologi yang tidak berkembang dan terhambat, baik dari segi infrastruktur maupun dari segi regulasi. Isu pengaturan terkait dengan alokasi spektrum dan ijin penyiaran masih harus diatasi di beberapa negara. Asia Tenggara juga memiliki banyak masalah infrastruktur domestik, seperti halnya Indonesia. Menemukan model bisnis yang berhasil jika mobile $T V$ memang 
terselenggara dengan baik. Hal ini membutuhkan kerjasama yang baik antara jaringan, penyedia isi siaran dan pengembang perangkat.

Sebagian layanan tersebut hanya dinikmati pada batas maksimal untuk kebutuhan hiburan, seperti halnya mobile TV. Sesuatu yang menyenangkan itu, menjadi kebutuhan masyarakat, dan kebutuhan banyak orang itu menjadi sesuatu yang menyenangkan bagi pihak industri atau korporasi.

Industri mobile $T V$ bisa dikatakan preumateur, karena lahir tanpa kesiapan dan bisa dibilang tidak begitu sukses. Masyarakat di Indonesia belum memanfaatkan teknologi secara fungsional maupun melihat dari sisi kualitas. Belum lagi akses yang membutuhkan biaya berlangganan. Salah satu faktor threat atau kompetitif adalah ketika antusiasme atau respon masyarakat yang terlihat tinggi terhadap layanan mobile $T V$ berbasis $D V B-H$ atau $3 G$ tersebut ditangkal oleh perkembangan ponsel $T V$ berbasis analog buatan China. Daripada harus membayar biaya langganan atau membayar akses data untuk menonton televisi, lebih baik membeli ponsel $T V$ analog yang dapat digunakan untuk menonton televisi, bahkan dengan harga handheld atau ponselnya yang cukup murah. Seperti hal nya perencanaan pelaksanaan penyelenggaraan televisi digital, meskipun dengan penerimaan publik yang positif alangkah baik direncanakan dengan sangat matang, daripada nantinya tidak dapat berjalan dengan baik. 


\section{Daftar Pustaka}

AGB Nielsen Newsletter, edisi ke-31 Maret 2009, Three Screen Circus: Definisi Ulang Kepemirsaan TV Asia dalam Dunia Digital, AGB Nielson.

Broadcastmagz No. 5, Tahun 1, 2011, Mobile TV: Diantara Standar dan Implementasi, Broadcastmagz.

Broadcastmagz No. 5, Tahun 1, 2011, Implementasi Mobile TV di Indonesia, Menanti Asa Pasca Uji Coba, Broadcastmagz

Fleury. A, Pederson, J. B, dan Larsen, B. O, Two Perspectives on Mobile Television: Consumption in a Social Context and Collaborative/ Competitive Behaviours, paper disajikan pada Danish Human-Computer Interaction Research Symposium, Aarhus, Denmark, 14 Desember 2009.

Flew, T, 2005, New Media: An Introduction, edisi 2, Oxford University Press.

Kitson, F, 2010, Mobile TV's Time to Shine Has Arrived dalam Mobile TV: Costumizing Content and Experience, Marcus. A, Roibas, A. C, dan Sala. R (Eds), Springer.

Lister. M, Dovie. J, Giddings. S, Grant. I, dan Kelly. K, 2003. New Media: A Crirical Introduction. Roudledge.

Qiantori. A, A. Sutiono, A. Budi, S. Hirahiko, dan O. Toshizumi, 2010, 3G Mobile TV Acceptance in Indonesia, paper disajikan pada 6th International Conference on Wireless and Mobile Communication,Valencia, Spain, 25-28

Youssef, A dan J. Haslett, 2010, Namometer CMOS RFICs for Mobile TV Application, Springer. September 2010 